\title{
POLA KOMUNIKASI PEMERINTAH DESA GUNTING KECAMATAN SUKOREJO KABUPATEN PASURUAN DALAM MELAKSANAKAN PROGRAM MATOANISASI
}

\author{
Silvia Amanatul Zuhriyah \\ Program Studi IImu Komunikasi, FISIP, Universitas Yudharta, Pasuruan, Jawa Timur, \\ Indonesia \\ Jedong Ngoro Mojokerto RT/RW 26/03 Jawa Timur 61385 \\ silviazuhriyah@gmail.com
}

\begin{abstract}
ABSTRAK
Dengan berbagai macam kekayaan alam dan potensi yang dimiliki oleh beberapa desa di Kabupaten Pasuruan menunjukkan bahwa Pasuruan merupakan suatu Kabupaten yang memiliki sumber daya alam melimpah. Program Matoanisasi merupakan suatu program unggulan yang ada di Kecamatan Sukorejo Kabupaten Pasuruan. Program ini dilakukan dengan tujuan untuk meningkatkan perekonomian masyarakat desa yang ada di Kecamatan Sukorejo. Desa Gunting merupakan salah satu desa yang ada di Kecamatan Sukorejo yang sudah melaksanakan program Motoanisasi mulai tahun 2015. Penelitian ini bertujuan untuk 1) mengetahui pola komunikasi yang dilakukan oleh pemerintah Desa Gunting dalam melaksanakan program Matoanisasi. Pendekatan yang dilakukan dalam penelitian ini adalah pendekatan kualitatif deskriptif. Teknik pengumpulan data yang digunakan adalah wawancara dan dokumentasi. Analisis data yang digunakan adalah model Miles dan Huberman (2012). Hasil penelitian menunjukkan, 1) pola komunikasi yang dilakukan oleh pemerintah Desa Gunting Kecamatan Sukorejo Kabupaten Pasuruan dalam melaksanakan program Matoanisasi ini adalah pola komunikasi rantai. 2) penyebaran informasi terkait dengan program Matoanisasi ini dilakukan oleh pemerintah Desa Gunting dengan cara sosialisasi dengan beberapa perwakilan desa kemudian seluruh informasi terkai dengan program Matoanisasi akan disebarkan kepada seluruh masyarakat yang ada di Desa Gunting Kecamatan Sukorejo Kabupaten Pasuruan.
\end{abstract}

Kata kunci: Pola Komunikasi, Program Matoanisasi

\section{ABSTRACT}

With a wide range of natural resources and potential of several villages in Pasuruan shows that Pasuruan is a district that has abundant natural resources. Matoanisasi program is a flagship program in the District SukorejoPasuruan. The program is conducted with the aim to improve the economy of rural communities in Sub Sukorejo. Scissors village is a village in the district which has been carrying out SukorejoMotoanisasi program started in 2015. This study aims to 1) determine the pattern of communications made by the village government in implementing the program Matoanisasi Scissors. The approach taken in this research is descriptive qualitative approach. Data collection techniques used were interviews and documentation. Analysis of the data used is the model of Miles and Huberman (2012). The results showed, 1) patterns of communication made by the village government Scissors Pasuruan District Sukorejo in implementing this Matoanisasi is a chain of communication patterns. 2) dissemination of information related to the program carried out by the government Matoanisasi Scissors village by way of socializing with several village representatives and then all the information terkai with Matoanisasi program will be distributed to all the people in the village of Pasuruan District Sukorejo Scissors. 1) patterns of communication made by the village government Scissors Pasuruan District Sukorejo in implementing this Matoanisasi is a chain of communication patterns. 2) dissemination of information related to the program carried out by the government Matoanisasi Scissors village by way of socializing with several village representatives and then all the information terkai with Matoanisasi program will be distributed to all the people in the village of Pasuruan District Sukorejo Scissors. 1) patterns of communication made by the village government Scissors Pasuruan District Sukorejo in implementing this Matoanisasi is a chain of communication patterns. 2) dissemination of information related to the program carried out by the government Matoanisasi Scissors village by way of socializing with several village representatives and then all the information terkai with Matoanisasi program will be distributed to all the people in the village of PasuruanDistrict Sukorejo Scissors. 


\section{PENDAHULUAN}

Sejak tahun 2014, kabupaten Pasuruan merencanakan program Inovasi Daerah, yakni program Desa Maslahat. Program Desa Maslahat bertujuan untuk meningkatkan kesejahteraan masyarakat desa tertinggal dengan memaksimalkan potensi desa tersebut. Desa Maslahat memiliki konsep "One Village One Product", dasar pelaksanaannya adalah dengan memaksimalkan potensi desa dan memprioritaskan satu produk unggulan dari desa yang bersangkutan. Terdapat 24 desa dari 24 kecamatan yang ditetapkan menjadi Desa Maslahat berdasarkan keputusan Bupati Pasuruan (Nomor: 400/670/HK/424.013/2014) tentang Penetapan Lokasi Program Desa Maslahat Kabupaten Pasuruan. Program Desa Maslahat dilaksanakan dengan sinergitas antara program atau kegiatan SKPD, Pemerintah Desa dan Masyarakat (pasuruankab.go.id).

Desa maslahat ini terdiri dari 1 desa terpilih dari 24 Kecamatan yang ada di Kabupaten Pasuruan. Dari seluruh Kecamatan akan dipilih satu desa yang nantinya di jadikan sebagai desa maslahat. Seperti di Kecamatan Sukorejo, yakni Desa Sukorame, Desa Sukorame menjadi desa maslahat yang sudah ditentukan oleh pemerintah Kabupaten Pasuruan di Kecamatan Sukorejo. Namun di Kecamatan Sukorejo juga terdapat beberapa desa lain yang memiliki potensi unggulan yang kemudian bisa dijadikan wujud dari potensi desa yang dimiliki oleh desa Maslahat. Salah satunya yakni Desa Gunting, Desa Gunting tidak termasuk desa maslahat yang ditentukan oleh pemerintah tetapi Desa Gunting memiliki beberapa potensi desa yang pantas untuk dijadikan sebagai produk unggulan desa yang kemudian bisa mengembangkan potensi desa dan nantinya bisa dijadikan sebagai wujud desa Maslahat. Dalam rangka menuju desa maslahat dengan mengembangkan usaha ekonomi desa, maka Desa Gunting menstimuli warganya untuk mengembangkan berbagai potensi yang dimiliki. Dalam hal ini keterlibatan penuh masyarakat desa agar terbangun penguasaan warga desa atas pengelolaan usaha, pemasaran dan distribusi. Hal tersebut oleh Camat Sukorejo Diano Vela Fery Santoso S.Sos. M.A diwujudkan berupa program matoanisasi atau dikenal dengan Sukorejo sebagai City Of Matoa yang digagas pada MUSRENGBANG Kecamatan Sukorejo yang dilaksanakan pada 11 Februari 2014.

Program Matoanisasi yaitu program penanaman bibit pohon matoa sebanyak 25.000 dalam kurun waktu dua tahun (2015-2016) dilahan sekitar rumah penduduk dengan cara penganggaran bibit di APBDes dan APBD. Dalam hal ini Kecamatan Sukorejo bekerja sama dengan perusahaan swasta yang ada (PT. HM. Sampoerna dan Yayasan Kaliandra Sejati Foundation) dalam mengadakan beberapa pelatihan untuk menambah pengetahuan kelompok tani dalam proses matoanisasi. Buah yang banyak tumbuh di Papua tersebut saat ini sudah tersebar di 19 Desa dengan total mencapai lebih dari 5500 tanaman. Ada beberapa desa di Kecamatan Sukorejo yang saat ini dapat ditemui tumbuh subur dan berbuah dibeberapa desa yakni di Desa Glagahsari, Mojotengah, Sukorejo dan Gunting. (sukorejo.pasuruankab.go.id). 
Potensi yang dimiliki oleh beberapa desa yang ada di Kecamatan Sukorejo memang berbeda dengan kecamatan lain. Bukan hanya bibit buah matoa saja yang berkembang tetapi beragam menu makanan dan minuman hasil olahan matoa yang sudah menyebar kemana-mana. Bahkan saat ini sudah ada batik dari matoa, batik matoa ini memiliki keunikan tersendiri daripada batik pada umumnya.

Sesuai dengan rekomendasi yang diberikan oleh pihak pemerintah Kecamatan Sukorejo bahwa Desa Gunting layak untuk dijadikan sebagai lokasi penelitian dikarenakan Desa Gunting memiliki potensi khas yakni pertumbuhan buah matoa yang subur dengan berbagai macam olahan lain diantaranya batik matoa. Program khusus ini dijadikan sebagai upaya untuk meningkatkan potensi masyarakat desa di Kecamatan Sukorejo yakni program Matoanisasi.

Desa yang sudah berhasil mengembangkan program Matoanisasi ini tidak akan optimal jika komunikasi yang terbangun didalamnya tidak efektif, terlebih lagi jika pola komunikasi secara internal tidak terbangun dengan baik. Pola komunikasi merupakan sebuah model dari proses komunikasi, sehingga dengan

\section{KAJIAN TEORI}

\section{Komunikasi}

Komunikasi menurut Harold Laswell adalah proses penyampaian pesan oleh komunikator kepada komunikan melalui media yang menimbulkan efek tertentu (Effendy, 2004:10). Dalam hal ini menunjukkan bahwa ilmu komunikasi bukan hanya penyampaian informasi, melainkan juga pembentukan pendapat adanya beraneka ragam model komunikasi dan bagian dari proses komunikasi akan dapat ditemukan pola yang cocok dan mudah digunakan untuk berkomunikasi. Pola komunikasi identik dengan proses komunikasi, karena pola komunikasi merupakan rangkaian dari aktivitas menyampaikan pesan sehingga diperoleh feedback dari penerima pesan, dari proses komunikasi akan timbul pola, model, bentuk dan juga bagian-bagian kecil yang berkaitan erat dengan proses komunikasi (Effendy, 2008:33)

Banyak faktor yang mempengaruhi berbagai macam perubahan yang terjadi. Namun sesuai dengan tujuan komunikasi menurut Effendy (2006:8) yakni tujuan komunikasi untuk mengubah sikap, pendapat, opini, pandangan perilaku, dan untuk mengubah masyarakat. Hal ini merupakan proses perubahan yang dilakukan oleh masyarakat Desa Gunting terkait dengan adanya program Matoanisasi. Melalui berbagai macam perubahan pola komunikasi yang dilakukan antara masyarakat desa dengan pihak pemerintahan adalah dengan tujuan untuk melaksanakan program Matoanisasi

umum dan sikap publik yang dalam kehidupan sosial dan kehidupan politik memainkan peranan yang amat penting.

\section{Pola Komunikasi}

Menurut Widjaja (2000:102-103) Pola

Komunikasi dibagi menjadi 4 (empat ) yaitu: 
1. Pola Komunikasi Roda

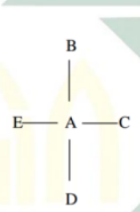

Gambar 1. Pola Komunikasi Roda

Pola Komunikasi roda menjelaskan pola komunikasi satu orang kepada orang banyak, yaitu (A) berkomunikasi kepada (B), (C), (D) dan (E).

\section{Pola Komunikasi Rantai}

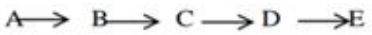

Gambar 2. Pola Komunikasi Rantai

Pola komunikasi ini, seseorang (A)

berkomunikasi dengan orang lain (B) seterusnya ke (C),

(D), dan (E)

3. Lingkaran

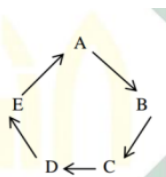

Gambar 3. Pola Komunikasi Lingkaran

Pola komunikasi ini hampir sama dengan pola komunikasi rantai, namun terakhir (E) berkomunikasi kembali pada orang pertama $(A)$

4. Bintang

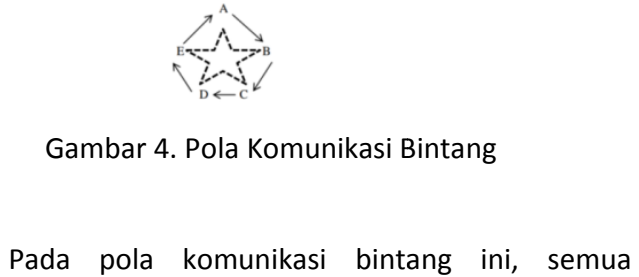
anggota saling berkomunikasi antara satu dengan yang lainnya.
Selain keempat pola komunikasi itu, menurut Rakhmat (2001:162-163), terdapat 5 (lima) pola komunikasi yaitu roda (wheel), rantai (chain), Y, lingkaran (circle), dan bintang (star atau networks).

Adapun pola komunikasi $\mathrm{Y}$ adalah pada pola ini pemimpin sudah dilihat dengan jelas, tetapi anggota lainnya berperan sebagai pemimpin kedua.Anggota ini dapat mengirim dan menyampaikan pesan dari dua orang anggota lainnya, sedangkan ketiga lainnya hanya dengan satu orang saja.<smiles>CC(C)C</smiles>

Gambar 5. Pola Komunikasi Y

Pola komunikasi yang dimaksudkan disini adalah gambaran tentang bentuk atau cara yang digunakan seseorang atau sekelompok orang dalam menyampaikan pesan baik secara langsung maupun melalui media dalam konteks hubungan dan interaksi yang berlangsung dimasyarakat.

\section{Komunikasi Kelompok}

Komunikasi kelompok adalah komunikasi yang berlangsung antara beberapa orang dalam suatu kelompok seperti dalam rapat, pertemuan, konferensi dan sebagainya. Michael Burgoon (Wiryantono:2005) mendefinisikan komunikasi kelompok sebagai interaksi secara tatap muka antara tiga orang atau lebih, dengan tujuan yang telah diketahui, seperti berbagi informasi, menjaga diri, pemecahan masalah, yang mana anggotaanggotanya dapat mengingat karakteristik pribadi anggota-anggota yang lain secara tepat. 


\section{Program Matoanisasi}

Program matoanisasi adalah salah satu program dari pemerintah Kecamatan Sukorejo yang dilakukan dengan tujuan untuk meningkatkan potensi masyarakat desa dengan produk buah Matoa. Selain fleksibel dalam hal tempat penanaman, Matoa memiliki tampilan daun yang indah dan cocok dijadikan sebagai tanaman hias. Matoa saat ini dapat ditemui dibeberapa desa yang tumbuh subur dan berbuah diantaranya yaitu Desa Glagahsari, Mojotengah, Sukorejo dan Gunting. (sukorjo.pasuruankab.go.id)

\section{METODE PENELITIAN}

Jenis Penelitian

Penelitian ini menggunakan jenis penelitian dengan menggunakan metode kualitatif deskriptif. Alasan peneliti menggunakan jenis penelitian kualitatif adalah untuk mengetahui pola komunikasi Pemerintah Desa Gunting Kecamatan Sukorejo Kabupaten Pasuruan dalam melaksanakan program Matoanisasi.

\section{Fokus Penelitian}

Fokus penelitian dalam sebuah penelitian dimaksudkan untuk membatasi studi sesuai dengan permasalahan yang dirumuskan. Penetapan fokus juga berfungsi untuk memenuhi serta memasukkanmengeluarkan suatu informasi yang diperoleh. Adapun fokus penelitian dari penelitian ini adalah pola komunikasi Pemerintah Desa Gunting Kecamatan Sukorejo Kabupaten Pasuruan dalam melaksanakan program Matoanisasi.

\section{Jenis dan Sumber Data}

1. Data Primer
Dalam penelitian ini data diperoleh langsung melalui observasi dan wawancara kepada masyarkat desa serta perwakilan dari pemerintah Desa Gunting yang bertanggung jawab penuh terhadap program matoanisasi di Kecamatan Sukorejo Kabupaten Pasuruan.

\section{Data Sekunder}

Data sekunder adalah data yang diperoleh dari sumber kedua. Data ini juga dapat diperoleh dari data primer penelitian terdahulu yang telah diolah lebih lanjut menjadi bentuk-bentuk seperti tabel, grafik, diagram, gambar dan sebagainya sehingga menjadi informatif bagi pihak lain. Karena data sekunder ini bersifat melengkapi data primer.Selain melengkapi, biasanya data sekunder ini sangat membantu peneliti bila data primer terbatas atau sulit diperoleh (Kriyantono, 2014:42).

\section{Teknik Pengumpulan Data}

Dalam penelitian ini, peneliti menggunakan beberapa cara untuk mengumpulkan data-data yang diperlukan. Oleh karena itu, peneliti menggunakan teknik pengumpulan data yang sesuai dengan penelitian ini yaitu:

\section{Wawancara}

Wawancara dalam penelitian kualitatif, ada wawancara secara mendalam (depth interview) atau wawancara intensif (intensive interview) dan kebanyakan tak terstruktur. Tujuannya adalah untuk mendapatkan data kualitatif yang mendalam (Kriyantono, 2014:100). Dalam hal ini peneliti melakukan wawancara secara mendalam kepada pemerintah Desa 
Gunting dan Masyarakat Desa Gunting Kecamatan Sukorejo.

Adapun yang menjadi karakteristik dari Key Informan dalam penelitian ini adalah:

1. Pemerintah Desa Gunting Informan :

1. Kepala Desa Gunting

2. Sekretaris Desa GuntingE

Dengan kriteria informan sebagai berikut:

1) Memahami tentang program Matoanisasi yang ada di Desa Gunting

2) Mengetahui keberhasilan program Matoanisasi yang ada di Desa Gunting

2. Masyarakat Desa Gunting

Dengan kriteria informan sebagai berikut:

1) Memahami dan mengetahui tentang program Matoanisasi di Desa Gunting

2) Berhasil melaksanakan Program Matoanisasi di Desa Gunting

2. Dokumentasi

Dokumentasi adalah pengumpulan data yang dilakukan untuk mendapatkan data sekunder berupa dokumen dan arsip, jurnal-jurnal komunikasi, dan website serta situs-situs resmi. Tujuannya adalah untuk mendapatkan informasi yang mendukung analisis dan interpretasi data (Kriyantono, 2014:120).

\section{Tknik Analisis Data}

Data yang telah diperoleh oleh peneliti akan dianalisis dengan model yang telah ditawarkan oleh Miles dan Huberman. Menurut Sugiono (2012:246) aktifitas dalam analisis data yaitu data reduction, data display, dan data consclusion drawing atau vertification.

1. Data Reduction (Reduksi Data)

Dalam reduksi data ini peneliti mengumpulkan semua data yang telah diperoleh. Kemudian semua data yang telah terkumpul diseleksi dan dikelompokkan sesuai dengan fokus penelitian.

2. Data Display (Penyajian Data)

Setelah data direduksi maka langkah selanjutnya adalah menyajikan data. Menyajikan data dilakukan dengan cara mengorganisasikan informasi yang sudah direduksi.

3. Vertification (Penarikan Kesimpulan)

Langkah ketiga adalah penarikan kesimpulan dan verifikasi. Kesimpulan awal yang dikemukakan masih bersifat sementara dan akan berubah bila tidak ditemukan bukti-bukti yang kuat yang mendukung pada tahap pengumpulan data berikutnya. Tetapi apabila kesimpulan awal sudah konsisten maka kesimpulan yang dikemukakan merupakan kesimpulan yang kredibel.

\section{HASIL DAN PEMBAHASAN}

1. Pola Komunikasi Pemerintah Desa Gunting kepada Masyarakat Desa Gunting terkait dengan pelaksanaan program Matoanisasi.

Program Matoanisasi adalah sebuah program yang dirintis oleh pemerintah Kecamatan Sukorejo kepada seluruh masyarakat Sukorejo dengan tujuan untuk meningkatkan perekonomian desa. Dalam hal ini penyebaran informasi dan komunikasi yang dilakukan antara pemerintah desa dengan masyarakat sangat penting, misalnya dalam hal pola komunikasi yang 
diterapkan oleh pemerintah desa kepada masyarakat desa dalam mewujudkan program Matoanisasi.

Selain itu masyarakat Desa Gunting juga bisa melakukan sharing bersama dan memahami dengan mudah terkait pelaksanaan program Matoanisasi contohnya: sosialisasi. Dalam program matoanisasi ini masyarakat desa tentunya membutuhkan beberapa sosialisasi terkait dengan program Matoanisasi, dengan adanya sosialisasi masyarakat akan lebih mudah memahami dan melaksanakan program Matoanisasi sesuai dengan apa yang sudah direncanakan oleh pemerintah Kecamatan Sukorejo.

Setelah peneliti melakukan beberapa wawancara terhadap informan, memang terdapat beberapa penjelasan terkait dengan proses komunikasi yang dilakukan oleh pemerintah desa kepada masyarakat. Diantaranya adalah sosialisasi, karena melalui proses sosialisasi ini masyarakat akan lebih mudah memahami program Matoanisasi. Proses sosialisasi ini dilakukan oleh pemerintah desa kepada beberapa perwakilan desa diantaranya yakni Kepala Dusun dan RT/RW. Setelah melakukan sosialisasi perwakilan dari masing-masing dusun akan membagikan beberapa informasi terkait dengan pelaksanaan program Matoanisasi.

\section{Konfirmasi Temuan Dengan Teori}

\section{Proses Komunikasi}

Dalam penelitian ini berdasarkan hasil temuan peneliti dilapangan peneliti setuju bahwa proses komunikasi sejalan dengan teori yang digunakan. Seperti teori yang sudah dikemukakan oleh Carl I. Hovland bahwa:
Ilmu komunikasi bukan hanya penyampaian informasi, melainkan juga pembentukan pendapat umum dan sikap publik yang dalam kehidupan sosial dan kehiduan politik memainkan peranan yang amat penting.

Michael Burgoon

(Wiryantono:2005) mendefinisikan komunikasi kelompok sebagai interaksi secara tatap muka antara tiga orang atau lebih, dengan tujuan yang telah diketahui, seperti berbagai informasi, menjaga diri, pemecahan masalah, yang mana anggota dapat mengingat secara tepat.

Jadi proses komunikasi yang dilakukan oleh pemerintah Desa Gunting adalah dengan cara komunikasi kelompok. Dalam hal ini yang pertama dilakukan adalah dengan mengumpulkan beberapa perwakilan desa untuk melakukan sosialisasi kemudian setelah itu memberikan informasi terkait dengan pelaksanaan program Matoanisasi agar supaya diketahui oleh seluruh masyarakat Desa Gunting.

\section{Pola Komunikasi}

Dalam penelitian ini peneliti memfokuskan pada pola komunikasi Pemerintah Desa Gunting Kecamatan Sukorejo Kabupaten Pasuruan. Peneliti menemukan beberapa temuan yang berkaitan dengan fokus penelitian. Setelah peneliti konfirmasi dengan teori pola komunikasi yang menjadi acuan peneliti.

Dalam penelitian ini berdasarkan hasil temuan peneliti dilapangan peneliti setuju bahwa proses pola komunikasi yang dilakukan oleh pemerintah Desa Gunting Kecamatan Sukorejo sejalan dengan teori yang dikemukakan oleh Widjaja (2000:102-103). 
Teori yang sesuai dengan temuan diatas adalah teori pola komunikasi Rantai, yang mana dalam hal ini pemimpin berperan aktif dalam memberikan informasi kepada seluruh anggota. Yang dalam hal ini dilakukan oleh pemerintah Desa Gunting kepada masing-masing Kepala Dusun kemudian Kepala Dusun memberikan informasi melalui RT/RW dan yang bterakhir kepada masyarakat Desa Gunting.

Dari hasil wawancara dengan informan maka didapatkan temuan dengan skema tentang pola komunikasi yang dilakukan oleh pemerintah Desa Gunting Kecamatan Sukorejo Kabupaten Pasuruan dalam melaksanakan program Matoanisasi.

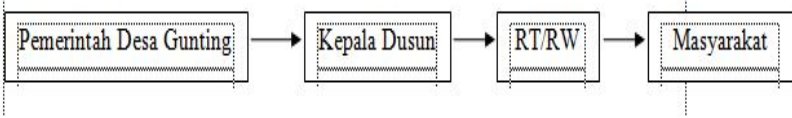

Dari skema diatas dapat dijelaskan bahwa pola komunikasi yang dilakukan oleh pemerintah Desa Gunting kepada masyarakat Desa Gunting terkait dengan pelaksanaan program Matoanisasi adalah dengan menggunkan pola rantai. Seperti yang sudah dikemukan oleh Widjaja.

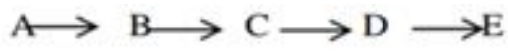

Gambar 6. Pola Komunikasi Rantai

Pada skema diatas menunjukkan bahwa dalam proses komunikasi nya pemerintah desa berperan aktif dalam penyebaran informasi pertama atau bisa dinamakan dengan sumber utama dalam penyebaran informasi di Desa Gunting, proses penyampaian infomasi ini dilakukan dengan cara sosialisasi antara komunikator dengan komunikan, komunikasi berjalan secara rileks, nyaman, dan santai sehingga mempermudah masyarakat dalam bertukar pikiran maupun informasi terkait dengan program Matoanisasi.

Dari pola komunikasi yang sudah dilakukan oleh pemerintah Desa Gunting terdapat pola komunikasi lain yang juga dilakukan oleh pemerintah Desa Gunting. Pola komunikasi tersebut adalah pola komunikasi roda. Dalam pola komunikasi roda ini seorang pemimpin biasanya dijadikan sebagai fokus perhatian, pemimpin bisa berhubungan dengan semua anggota kelompok tetapi setiap anggota kelompok hanya bisa berhubungan langsung dengan pemimpinnya.

Dalam hal ini pemerintah Desa Gunting bisa melakukan komunikasi kepada seluruh perwakilan dari desa dan setiap perwakilan desa bisa langsung melakukan komunikasi kepada pemerintah desa secara langsung.

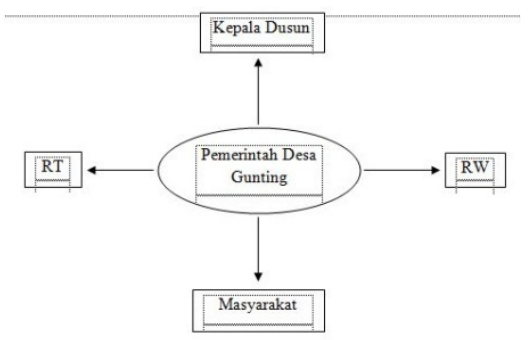

Dari skema diatas dapat dijelaskan bahwa pola komunikasi yang dilakukan oleh pemerintah Desa Gunting kepada masyarakat Desa Gunting terkait dengan pelaksanaan program Matoanisasi adalah dengan menggunkan pola roda. Seperti yang sudah dikemukan oleh Widjaja.

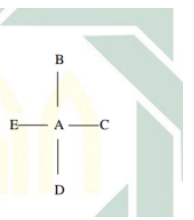

Gambar 7. Pola Komunikasi Roda 
Pada skema diatas menunjukkan bahwa dalam proses komunikasi nya pemerintah Desa Gunting berperan penting dalam penyebaran informasi, mengingat bahwa pemerintah desa menjadi fokus perhatian dalam penyampaian informasi, pemerintah memiliki hak penuh dalam penyampaian informasi kepada setiap anggota, tetapi anggota kelompok hanya bisa berkomunikasi langsung kepada pemimpin. Dalam hal ini mengenai penyebaran informasi masyarakat tidak harus bertanya kepada perwakilan desa melainkan bertanya langsung kepada pemerintah Desa Gunting seperti Kepala Desa dan staff yang ada di pemerintahan Desa Gunting terkait dengan pelaksanaan program Matoanisasi.

Dari sekian data yang diperoleh oleh peneliti, ditemukan bahwa proses komunikasi yang dilakukan oleh pemerintah Desa Gunting ada keterkaitan dengan fokus penelitian. Setelah peneliti melakukan konfirmasi terkait dengan fokus penelitian dengan teori pola komunikasi yang menjadi acuan peneliti, ternyata memang terdapat keterkaitan antara teori yang sudah dirumuskan dengan fokus penelitian yang dilakukan oleh peneliti di Desa Gunting Kecamatan Sukorejo Kabupaten Pasuruan terkait dengan pola komunikasi pemerintah Desa Gunting dalam melaksanakan program Matoanisasi.

\section{KESIMPULAN}

Berdasarkan penelitian yang telah dilakukan, maka peneliti mendapatkan beberapa kesimpulan sebagai berikut:
1. Pola komunikasi yang dilakukan oleh Pemerintah Desa Gunting kepada masyarakat Desa Gunting terkait dengan pelaksanaan program Matoanisasi ini adalah pola komunikasi rantai dan pola komunikasi roda. Pola komunikasi rantai merupakan suatu pola komunikasi yang di dalamnya ada seorang komunikator yang menjadi pemimpin dalam penyampaian informasi kemudian ada komunikan yang nantinya akan melakukan penyebaran informasi lebih lanjut kepada masyarakat yang lain. Sedangkan untuk pola komunikasi roda didalamnya terdapat pola komunikasi yang di fokuskan kepada pemerintah desa, untuk penyebaran informasi terkait dengan pelaksanaan program Matoanisasi masyarakat bisa langsung berkomunikasi dengan pemerintah tanpa melalui perantara dari pihak yang sudah ditentukan.

2. Penyebaran informasi terkait program Matoanisasi ini dilakukan oleh Pemerintah Desa Gunting dilakukan dengan cara sosialisasi bersama dengan beberapa perwakilan desa, kemudian setelah melakukan sosialisasi masyarakat akan diberikan beberapa informasi terkait dengan pelaksanaan program Matoanisasi. Dalam hal ini penyebaran informasi pertama kali dilakukan oleh pemerintah desa kepada perwakilan desa. Kemudian perwakilan desa atau yang biasa di wakili oleh Kepala Dusun nantinya akan menyebarkan kepada seluruh RT/RW dan yang terakhir informasi akan di sampaikan kepada masyarakat.

\section{SARAN}

1. Bagi Tempat Penelitian

1) Pola komunikasi yang sudah dilakukan oleh Pemerintah Desa Gunting adalah pola komunikasi rantai 
dan pola komunikasi roda. Dalam hal pola komunikasi rantai masyarakat hanya bisa menunggu informasi yang disampaikan melalui perantara informan yang memang sudah ditunjuk oleh pemerintah desa dengan cara sosialisasi bersama khusus dengan masyarakat yang nantinya akan lebih mempermudah masyarakat dalam pemahaman terkait dengan pelaksanaan program Matoanisasi tersebut.

2) Program matoanisasi ini sangat bermanfaat bagi masyarakat terutama dalam hal peningkatan kesejahteraan ekonomi masyarakat. Motivasi dan dorongan dari pemerintah desa langung kepada masyarakat sangat dibutuhkan dengan tujuan untuk meningkatkan antusias masyarakat yang nantinya juga akan meberikan dampak positif kepada masyarakat yang memang memiliki beberapa masalah terkait dengan perekonomian.

\section{Bagi Peneliti Selanjutnya}

Bagi peneliti selanjutnya disarankan untuk lebih memperdalam tentang pola komunikasi yang dilakukan oleh pemerintah Kecamatan terlebih dahulu. Dikarenakan program matoanisasi ini merupakan suatu program unggulan yang memang di gagas oleh pemerintah Kecamatan Sukorejo Kabupaten Pasuruan dengan tujuan untuk meningkatkan perekonomian masyarakat di Kecamatan Sukorejo.

\section{DAFTAR PUSTAKA}

Buku :

Bungin, Burhan. 2009. Sosiologi Komunikasi. Jakarta:Kencana
Devito, Joseph A. 1997. Komunikasi Antar Manusia. Edisi 5. Jakarta: Profesional Books

Kriyantono, Rahmat. 2008. Teknik Praktis Riset Komunikasi. Jakarta: Kencana

Moleong, Lexy J. 2005. Metodologi Penelitian Kualitatif. Bandung:Remaja Rosdakarya

Mulyana, Deddy. 2000. Ilmu Komunikasi Suatu Pengantar. Bandung: PT Remaja Rosdakarya

Onong Uchjana Effendy.2008.Dinamika Komunikasi.Bandung:PT Remaja Rosdakarya

Onong Uchjana Effendy.2009.IImu Komunikasi Teori dan Praktej.Bandung:PT Remaja Rosdakarya

Onong Uchjana, Effendy.2004. Ilmu komunikasi Teori Dan Praktek. Bandung:Remadja Karya.

Sugiono.2012.Metode Penelitian Kuantitatif, Kualitatif, dan R\&D. Bandung : Alfabeta

Sutopo. 2002. Metodologi Penelitian Kualitatif. Surakarta: Sebelas Maret University Press

Widjaja. 2000. Ilmu Komunikasi Pengantar Studi. Jakarta: Rineka Cipta

Jurnal :

Aditya Oktendy Saputra. 2012. Memahami Pola Komunikasi Kelompok Antar Anggota Komunitas Punk Di Kota Semarang.Jurnal The Messenger. Vol 4 No.1

Andreano Rinaldi Sitinjak. 2013. Pola Komunikasi Public Relation Officier Dalam Mempertahankan Citra PT. Lion Air Indonesia Cabang Manado. Journal "Acta Diurna "Vol.1 No.1

Aulia Vera Rozida. 2011. Pola Komunikasi Masyarakat Suku Nuhatan Sebagai Dampak Akulturasi Budaya. Jurnal Reformasi.Vol 1 No.1

Internet :

http://sukorejo.pasuruankab.go.id/berita-631-buah-

matoa-tumbuh-di-sukorejo.html di akses pada Selasa,

10 April 2018 . 10.27 WIB 